\title{
Research Article: An economic analysis of resource use efficiency of SRI and non-SRI in Vellore district of Tamil Nadu
}

Article Chronicle : Received : 11.07.2017;

Accepted : 24.07.2017

KeY WoRds :

Resource use efficiency, Technical efficiency, Garrett's score, SRI, Non- SRI

Author for correspondence :

\section{R. LOGANATHAN}

Department of

Agriculture,

Adhiparasakthi

Agricultural College,

(T.N.A.U.) VELLORE (T.N.)

INDIA

See end of the article for

authors' affiliations

\section{口 R. LOGANATHAN, N. YUVARAJA, U. PRAGADHEESWARAN, S. NANDHAKUMAR AND U. NAVEENA}

SUMMARY : Rice is the staple food for about 50 per cent of the world's population that resides in Asia, where 90 per cent of the world's rice is grown and consumed.Major objectives are to estimate technical and allocative efficiency in traditional and SRI methods of paddy cultivation and to examine reasons for adopting SRI and problems faced by traditional farmers in adopting SRI in Vellore district of Tamil Nadu.Two major paddy growing blocks were selected. From each block, six major paddy growing villages was selected. Totally ten farmers were selected from each village comprising five farmers for SRI method and five farmers for traditional method of rice cultivation and the total sample size was 120. Descriptive statistical analysis, Garrett's Ranking Technique,etc was used the tools of analysis in research. The co-efficient of multiple determination $\left(\mathrm{R}^{2}\right)$ was 0.99 for estimated production function of traditional method and it was 0.98 for SRI method. The SRI methods farmers could maximize their profit by using more quantities of seeds, labour, fertilizer, FYM and expenditure on PPC and miscellaneous items as the MVP-MFC ratio for all these resources was more than one.The average technical efficiency for traditional paddy and SRI paddy farmers was 0.88 and 0.99 , respectively. The average economic efficiency for traditional paddy farmers and SRI paddy farmers was 0.80 and 0.94 , respectively.It could be seen from the table that allocative efficiency $(0.91)$ of traditional paddy farmers was less than the allocative efficiency of SRI paddy farmers (0.95).

How to cite this article : Loganathan, R., Yuvaraja, N., Pragadheeswaran, U., Nandhakumar, S. and Naveena, U. (2017). An economic analysis of resource use efficiency of SRI and non-SRI in Vellore district of Tamil Nadu. Agric. Update, 12(TECHSEAR-2) : 479-484; DOI: 10.15740/HAS/AU/12.TECHSEAR(2)2017/479-484. 